ARTIKEL PENELITIAN

\title{
ANALISIS PENDAPATAN KELUARGA, BIAYA PERSALINAN, AKSES INFORMASI, DAN KEPESERTAAN JAMINAN KESEHATAN NASIONAL, DENGAN PEMILIHAN TEMPAT PERSALINAN DI KELURAHAN MUARA RAPAK KOTA BALIKPAPAN
}

\author{
Yona Palin $\mathbf{T}^{1}$, Handry Darussalam ${ }^{2)}$, Eli Rahmawati ${ }^{3)}$ \\ 1), 2), 3) Poltekkes Kemenkes Kalimantan Timur, Balikpapan 76125 \\ Email: yonapalint@yahoo.co.id
}

\begin{abstract}
Until the end of 2015, Indonesia had the opportunity to fail to achieve the MDG targets. The MDG target for the Maternal Mortality Rate in 2015 was 102 per 100,000 births. This optimism was reconsidered after seeing the results of 2012 which experienced a significant increase of 359 per 100,000 births. Births in Muara Rapak Village area in 2016 were 598 live births and 2 born deads. A total of 597 births were helped in health facilities and 3 births were assisted by Traditional Birth Attendants / at home. The purpose of this study was to analyze the relationship of family income, birth costs, access to information, participation in National Health Insurance, with the selection of places of birth in Muara Rapak Village, Balikpapan Town. This study used a cross sectional design. The data collection technique was accidental sampling with a sample of 92 mothers who brought infants to visit the Muara Rapak Health Center, from October to November 2018. Data analysis techniques used bivariate data analysis with Chi Square test, $p_{-}$value $>\alpha(0.05)$ concluded there was no relationship between variables. There were $79.3 \%$ of respondents choosing the place of birth at the hospital, $10.9 \%$ of respondents choosing the place of birth the maternity clinic, $6.5 \%$ choosing the place of birth at the Independent Practice Midwife, and 3.3\% of respondents choosing the place of birth by Traditional Birth Attendants / at home. The results of statistical tests, for family income variables the value of $p=0.967$, for birth of costs the value of $p=0.496$, for access to information the value of $p=0.867$, which means the value of $p>0.05$, and for participation in National Health Insurance the value of $p=0.001<0.05$. There is no relationship between family income, birth of costs, access to information, with the choice of place of birth. But between the participation of the National Health Insurance and the choice of place of birth, there is a relationship.
\end{abstract}

Keywords: Income, costs, access to information, NHI, place of birth

\begin{abstract}
Hingga akhir tahun 2015, Indonesia berpeluang gagal mencapai sasaran-sasaran MDGs.Target MDG's untuk Angka Kematian Ibu tahun 2015 adalah sebesar 102 per 100.000 Kelahiran Hidup. Optimisme tersebut menjadi pertimbangan kembali setelah melihat hasil tahun 2012 yang mengalami kenaikan signifikan yaitu sebesar 359 per 100.000 Kelahiran Hidup. Kelahiran di wilayah Kelurahan Muara Rapak pada tahun 2016 sebanyak 598 lahir hidup dan 2 lahir mati. Sebanyak 597 kelahiran ditolong di fasilitas kesehatan dan 3 kelahiran ditolong oleh dukun beranak / di rumah. Tujuan penelitian ini adalah untuk menganalisis hubungan pendapatan keluarga, biaya persalinan, akses informasi, kepesertaan Jaminan Kesehatan Nasional, dengan pemilihan tempat persalinan di Kelurahan Muara Rapak Kota Balikpapan. Penelitian ini menggunakan rancangan cross sectional. Teknik pengumpulan data adalah accidental sampling dengan jumlah sampel 92 ibu yang membawa bayi berkunjung ke Puskesmas Muara Rapak, mulai Oktober sampai dengan Nopember 2018. Teknik analisa data menggunakan analisis data bivariat dengan uji Chi Square, p_value $>\alpha(0,05)$ disimpulkan tidak ada hubungan antar variabel. Terdapat $79.3 \%$ responden memilih tempat persalinan di rumah sakit, $10.9 \%$ responden memilih tempat persalinan di klinik bersalin, 6.5\% memilih tempat bersalin di Bidan Praktek Mandiri, dan $3.3 \%$ responden memilih tempat persalinan di dukun beranak/di rumah. Hasil uji statistik, untuk variabel pendapatan keluarga nilai $\mathrm{p}=0.967$, untuk biaya persalinan nilai $\mathrm{p}=0.496$, untuk akses informasi nilai $\mathrm{p}=0.867$, yang berarti nilai $\mathrm{p}>0.05$, dan untuk kepesertaan Jaminan Kesehatan
\end{abstract}


Nasional nilai $\mathrm{p}=0.001<0.05$. Kesimpulan Tidak ada hubungan antara pendapatan keluarga, biaya persalinan, akses informasi, dengan pemilihan tempat persalinan. Namun antara kepesertaan Jaminanan Kesehatan Nasional dengan pemilihan tempat persalinan, terdapat hubungan.

Keywords: Pendapatan, biaya persalinan, akses informasi, JKN, tempat persalinan

\section{PENDAHULUAN}

Resiko kematian maternal dinegara maju adalah 1 diantaranya 4.000-10.000, sedangkan di negara berkembang 1 diantara 15-50, yang berarti peningkatan 200-250 kali.(Prawirohardjo, 2005) Faktor mendasar mencakup status ibu, status keluarga, status masyarakat, yang umumnya masih rendah yang membuat akses pelayanan kesehatan yang tidak memadai.

Di negara-negara Asssociation of the South East Asia Nation (ASEAN), kelahiran tertinggi adalah 20 per 1000 Kelahiran Hidup.Target Angka Kematian Bayi dalam Millenium Development Goal's (MDG's) 2015 adalah 23 per 1000 Kelahiran Hidup.(Indonesia, 2012) Hingga akhir tahun 2015, Indonesia berpeluang gagal mencapai sasaransasaran MDG's. Target-target yang berpeluang gagal untuk dicapai itu di antaranya penurunan angka kematian ibu dan penurunan angka kematian
Balita.(Hoelman, Parhusip, Eko, Bahagijo, \& Santono, 2015)

Persalinan adalah rangkaian proses yang berakhir dengan pengeluaran hasil konsepsi oleh ibu. Proses ini mulai dengan kontraksi persalinan sejati, yang ditandai oleh perubahan progesif pada serviks dan diakhiri dengan pelahiran plasenta.(Helen Varney, H.Kriebs, 2007) Tanda bahaya pada masa persalinan diantaranya adalah bayi tidak lahir dalam 24 jam untuk primigravida dan 18 jam untuk multigravida sejak terasa mulas.(Manuaba, 2006) Tenaga yang dapat memberikan pertolongan selama persalinan dapat dibedakan menjadi dua yaitu tenaga kesehatan (mereka yang mendapatkan pendidikan formal seperti dokter spesialis, dokter umum, bidan dan perawat bidan) dan bukan tenaga kesehatan, yaitu dukun bayi yang terlatih dan tidak terlatih.(Prawiroharjo, 2011) 
Tempat persalinan berupa fasilitas kesehatan terdiri yaitu: Rumah Sakit, Rumah Bersalin / klinik / praktik bidan, Puskesmas/Puskesmas pembantu, Pondok Bersalin Desa (Polindes), Pos Kesehatan Desa, serta di non fasilitas kesehatan meliputi rumah.(Kesehatan, 2010)

Berdasarkan Survei Demografi dan Kesehatan Indonesia (SDKI) 2007, data Angka Kematian Ibu sebesar 228 per $100.000 \mathrm{KH}$, mengalami penurunan jika dibandingkan dengan AKI tahun 2002 yaitu 307 per $100.000 \mathrm{KH}$. Data AKI tersebut membuat Indonesia mulai optimis bahwa target MDG's untuk AKI tahun 2015 adalah sebesar 102 per $100.000 \mathrm{KH}$ dapat tercapai. Optimisme tersebut menjadi kecemasan setelah melihat hasil SDKI 2012 bahwa AKI tercatat mengalami kenaikan yang signifikan yaitu sebesar 359 per $100.000 \mathrm{KH}$, sedangkan untuk data AKB di Indonesia walaupun masih jauh dari angka target MDGs yaitu AKB tahun 2015 sebesar 23 per 1000 kelahiran hidup tetapi tercatat mengalami penurunan yaitu dari sebesar 35 per
1.000 KH (SDKI 2002), menjadi sebesar 34 per 1000 KH (SDKI 2007), dan terakhir menjadi 32 per 1000 kelahiran hidup.(International, 2013)

Profil kesehatan tahun 2016 Dinas Kesehatan Kota Balikpapan menyebutkan bahwa distribusi persalinan pada tenaga kesehatan sebanyak 12.283 (95.13\%) dan persalinan oleh non tenaga kesehatan sebanyak 39 (0.29\%). Persalinan pada non tenaga kesehatan yang dimaksud adalah persalinan oleh dukun atau lahir di rumah. Dukun beranak yang masih melakukan pelayanan persalinan dijumpai di wilayah Balikpapan Barat, Timur dan Utara.(Balikpapan, 2016)

Hasil studi pendahuluan yang dilakukan peneliti di Puskesmas Muara Rapak diperoleh data : pada tahun 2016 sebanyak 600 kelahiran, terdiri dari kelahiran hidup 598 dan 2 lahir mati. Sebanyak 597 kelahiran ditolong oleh tenaga kesehatan dan 3 kelahiran ditolong non tenaga kesehatan. Tingginya persalinan pada tenaga kesehatan menunjukkan keberhasilan sosialisasi dan edukasi kepada masyarakat serta 
ditingkatkannya jumlah sarana antara lain bertambahnya fasilitas Puskesmas perawatan yang melayani persalinan di Kota Balikpapan.(Balikpapan, 2016)

\section{METODE PENELITIAN}

\section{Desain studi}

Jenis penelitian yang digunakan dalam penelitian ini adalah deskriptif analitik dengan menggunakan pendekatan kuantitatif. Penelitian ini menggunakan rancangan penelitian cross sectional. Penelitian ini dilakukan bulan Oktober sampai dengan Nopember 2018. Tempat penelitian dalam wilayah kerja Puskesmas Muara Rapak Kecamatan Balikpapan Utara.

Populasi adalah ibu yang membawa bayi, yang berkunjung ke Puskesmas Muara Rapak pada dan responden berdomisili di Kelurahan Muara Rapak sebanyak adalah 92 ibu. Seluruh populasi diambil sebagai sampel, dengan pengambilan sampel non probability sampling. Teknik yang digunakan adalah accidental sampling yaitu pengambilan kasus atau responden yang kebetulan ada atau tersedia.(Notoatmodjo, 2012)

\section{Metode analisis}

Analisa data dengan analisa univariat yang ditampilkan dalam bentuk table distribusi frekuensi dan analisa bivariat untuk melihat tabulasi silang guna melihat hubungan variabel independent dengan variabel dependent. Uji yang digunakan dalam analisis ini adalah Chi Square. Penelitian ini telah disetujui oleh Komite Etik Penelitian Kesehatan Poltekkes Kemenkes Kaltim.

\section{HASIL DAN PEMBAHASAN}

Tabel 1 Distribusi Frekuensi Variabel Pemilihan Tempat Persalinan

\begin{tabular}{|c|c|c|c|}
\hline \multirow[t]{2}{*}{ Variabel Determinan } & \multicolumn{2}{|c|}{ Frekuensi } & \multirow[t]{2}{*}{ Total } \\
\hline & $\mathbf{N}$ & $\%$ & \\
\hline \multicolumn{4}{|l|}{ Usia } \\
\hline$<20,>35$ & 22 & 23.9 & 92 \\
\hline $20-35$ & 70 & 76.1 & \\
\hline \multicolumn{4}{|l|}{ Pendidikan } \\
\hline $\mathrm{SD}$ & 10 & 10.9 & 92 \\
\hline SLTP-SLTA & 70 & 76.1 & \\
\hline PT & 12 & 13.0 & \\
\hline
\end{tabular}




\begin{tabular}{|c|c|c|c|}
\hline \multicolumn{4}{|l|}{ Paritas } \\
\hline Primipara & 18 & 19.6 & \multirow[t]{2}{*}{92} \\
\hline Multi-grandepara & 74 & 80.4 & \\
\hline \multicolumn{4}{|l|}{ Pendapatan } \\
\hline$\leq \mathrm{UMK}$ & 25 & 27.2 & \multirow[t]{2}{*}{92} \\
\hline > UMK & 67 & 72.8 & \\
\hline \multicolumn{4}{|l|}{ Biaya Bersalin } \\
\hline Mahal & 33 & 35.9 & \multirow[t]{2}{*}{92} \\
\hline Murah & 59 & 64.1 & \\
\hline \multicolumn{4}{|l|}{ Akses Informasi } \\
\hline Tidak dapat Informasi & 14 & 15.2 & \multirow[t]{2}{*}{92} \\
\hline Dapat Informasi & 78 & 84.8 & \\
\hline \multicolumn{4}{|l|}{ Peserta Jaminan Kesehatan } \\
\hline Nasional & 87 & 94,6 & \multirow[t]{5}{*}{92} \\
\hline Jaminan Kesehatan Nasiona & 5 & 5,4 & \\
\hline Tidak Jaminan Kesehatan & & & \\
\hline Nasional & & & \\
\hline \multicolumn{3}{|c|}{ Pemilihan Tempat Persalinan } & \\
\hline Rumah Sakit & 73 & 79.3 & 92 \\
\hline Bidan Praktek Mandiri & 6 & 6.5 & \\
\hline Klinik Bersalin & 10 & 10.9 & \\
\hline Dukun Beranak / di rumah & 3 & 3.3 & \\
\hline
\end{tabular}

Tabel 1 menunjukkan distribusi frekuensi dari 92 responden untuk variabel usia terbanyak pada usia 20 35 sebanyak $70(76.1 \%)$ responden. Variabel pendidikan kategori terbanyak yang berpendidikan SLTP-SLTA sebanyak $70 \quad(76.1 \%)$ responden. Variabel paritas terbanyak $71 \quad(80.4 \%)$ paritas multipara-grande multipara. Pendapatan keluarga terbanyak memiliki pendapatan lebih dari Upah Minimum Kota sebanyak 67 responden $(72.8 \%)$. Variabel biaya persalinan, terbanyak biaya persalinan kurang dari Rp 1.000 .000 sebanyak $59(64.1 \%)$ responden. Variabel akses informasi terbanyak respoden yang mendapat akses informasi sebanyak $78 \quad(84.8 \%)$ responden.

Variabel peserta Jaminan Kesehatan Nasional, terbanyak 87 (94.6\%) responden memiliki kartu peserta Jaminan Kesehatan Nasional. Tempat persalinan yang paling banyak dipilih 73 (79.3\%) responden memilih rumah sakit 
Tabel 2 Hubungan Pendapatan Keluarga dengan Pemilihan Tempat Persalinan

\begin{tabular}{|c|c|c|c|c|c|c|c|c|c|c|}
\hline \multirow[t]{3}{*}{ Pendapatan } & \multicolumn{8}{|c|}{ Tempat Persalinan } & \multirow[t]{2}{*}{ Total } & \multirow[t]{3}{*}{ P_value } \\
\hline & \multicolumn{2}{|c|}{ RS } & \multicolumn{2}{|c|}{ BPM } & \multicolumn{2}{|c|}{ Klinik } & \multicolumn{2}{|c|}{ Dukun } & & \\
\hline & $\mathbf{n}$ & $\%$ & n & $\%$ & $\mathbf{n}$ & $\%$ & $\mathbf{n}$ & $\%$ & $\mathbf{n}$ & \\
\hline$\leq \mathrm{UMK}$ & 19 & 76 & 2 & 8 & 3 & 12 & 1 & 4 & 25 & 0.967 \\
\hline >UMK & 54 & 80.6 & 4 & 6 & 7 & 10.4 & 2 & 3 & 67 & \\
\hline Total & 73 & 79.3 & 6 & 6.5 & 10 & 10.9 & 3 & 3.3 & 92 & \\
\hline
\end{tabular}

Berdasarkan tabel

2. menunjukkan hubungan faktor pendapatan keluarga dengan pemilihan tempat persalinan yaitu pendapatan kurang dari UMK Rp 2.618.345, terbanyak memilih tempat persalinan di rumah sakit sebanyak 19 (76\%) responden, memilih tempat persalinan kedua di klinik bersalin sebanyak $3(12 \%)$ responden, kemudian memilih tempat persalinan ketiga di BPM sebanyak 2 (8\%) responden, dan memilih tempat bersalin di dukun beranak / di rumah sebanyak 1 (4\%) responden. Sedangkan hubungan faktor pendapatan keluarga dengan pemilihan tempat persalinan yaitu pendapatan lebih dari UMK terbanyak memilih tempat persalinan di rumah sakit sebanyak 54 (80.6\%) responden, memilih tempat persalinan kedua di klinik bersalin sebanyak 7 (10.4\%) responden, kemudian memilih tempat persalinan ketiga di BPM sebanyak $4(6 \%)$ responden, dan memilih tempat bersalin di dukun beranak / di rumah sebanyak $2(3 \%)$ responden.

Hasil uji statistik Chi-Square diperoleh nilai $\mathrm{p}=0.967$ dengan demikian $p \_v a l u e>\alpha$ sehingga $\mathrm{H} 0$ di terima, berarti tidak ada hubungan pendapatan dengan pemilihan tempat persalinan oleh ibu di Kelurahan Muara Rapak.

Tabel 3 Hubungan Biaya Persalinan dengan Pemilihan Tempat Persalinan

\begin{tabular}{|c|c|c|c|c|c|c|c|c|c|c|}
\hline \multirow{3}{*}{$\begin{array}{l}\text { Biaya } \\
\text { Bersalin }\end{array}$} & \multicolumn{8}{|c|}{ Tempat Persalinan } & \multirow{3}{*}{ Total } & \multirow[b]{2}{*}{ P_value } \\
\hline & $\mathbf{R S}$ & & BPM & & Klinik & & uk & & & \\
\hline & $\mathbf{n}$ & $\%$ & $\mathbf{n}$ & $\%$ & $\mathbf{n}$ & $\%$ & $\mathbf{n}$ & $\%$ & & \\
\hline Mahal & 27 & 81.8 & 3 & 9.1 & 3 & 9.1 & 0 & 0 & 33 & 0.496 \\
\hline Murah & 46 & 78 & 3 & 5.1 & 7 & 11.9 & 3 & 5.1 & 59 & \\
\hline Total & 73 & 79.3 & 6 & 6.5 & 10 & 10.9 & 3 & 3.3 & 92 & \\
\hline
\end{tabular}


Berdasarkan tabel 3 .menunjukkan hubungan faktor biaya persalinan dengan pemilihan tempat persalinan yaitu biaya lebih dari Rp. 1.000 .000 terbanyak memilih tempat persalinan di rumah sakit sebanyak $27(81.8 \%)$ responden, yang kedua memilih tempat persalinan di klinik bersalinsebanyak $\quad 3 \quad(9.1 \%)$ responden, yang memilih bersalin di BPM sebanyak 3 (9.1\%), dan tidak memilih tempat bersalin di dukun sebanyak 0 responden. Sedangkan hubungan faktor biaya persalinan dengan pemilihan tempat persalinan yaitu biaya kurang dari Rp. 1.000.000 dengan kategori murah terbanyak memilih tempat persalinan di rumah sakit sebanyak $46 \quad(78 \%)$ responden, yang memilih tempat persalinan di klinik bersalin sebanyak 7 (11.9\%) responden, yang memilih bersalin di BPM sebanyak 3 (5.1\%) responden, dan memilih tempat bersalin di dukun beranak / di rumah sebanyak $3(5.1 \%)$ responden.

Hasil uji statistik Chi-Square diperoleh nilai $\mathrm{p}=0.496$ dengan demikian $p \_v a l u e>\alpha$ sehingga $\mathrm{H} 0$ di terima, berarti tidak ada hubungan biaya bersalin dengan pemilihan tempat persalinan oleh ibu di Kelurahan Muara Rapak.

Tabel 4 Hubungan Akses Informasi dengan Pemilihan Tempat Persalinan

\begin{tabular}{|c|c|c|c|c|c|c|c|c|c|c|}
\hline \multirow[t]{3}{*}{ Akses Informasi } & \multicolumn{9}{|c|}{ Tempat Persalinan } & \multirow[t]{3}{*}{ P_value } \\
\hline & \multicolumn{2}{|c|}{ RS } & \multicolumn{2}{|c|}{ BPM } & \multicolumn{2}{|c|}{ Klinik } & \multicolumn{2}{|c|}{ Dukun } & Total & \\
\hline & $\mathbf{n}$ & $\%$ & $\mathbf{n}$ & $\%$ & $\mathbf{n}$ & $\%$ & $\mathbf{n}$ & $\%$ & $\mathbf{n}$ & \\
\hline Tidak dapat & 11 & 78.6 & 1 & 7.1 & 2 & 14.3 & 0 & 0 & 14 & 0.867 \\
\hline Informasi & 62 & 79.5 & 5 & 6.4 & 8 & 10.3 & 3 & 3.8 & 78 & \\
\hline $\begin{array}{l}\text { Dapat Informasi } \\
\text { Total }\end{array}$ & 73 & 79.3 & 6 & 6.5 & 10 & 10.9 & 3 & 3.3 & 92 & \\
\hline
\end{tabular}


Berdasarkan tabel 4 menunjukkan hubungan faktor akses informasi dengan pemilihan tempat persalinan yaitu kategori tidak dapat informasi terbanyak memilih tempat persalinan di rumah sakit sebanyak 11 (78.6\%) responden, yang kedua memilih tempat persalinan di klinik bersalin sebanyak 2 (14.3\%) responden, memilih bersalin di BPM sebanyak 1 (7.1\%), dan tidak memilih tempat bersalin di dukun / di rumah sebanyak 0 responden. Sedangkan hubungan faktor akses informasi dengan pemilihan tempat persalinan yaitu kategori mendapatkan informasi terbanyak memilih tempat persalinan di rumah sakit sebanyak $62 \quad(79.5 \%)$ responden, yang kedua memilih tempat persalinan di klinik bersalin sebanyak 8 (10.3\%) responden, memilih bersalin di BPM sebanyak 5 (6.4\%), dan memilih tempat bersalin di dukun/ di rumah sebanyak 3 (3.8\%) responden.

Hasil uji statistik Chi-Square diperoleh nilai $\mathrm{p}=0.867$ dengan demikian $p_{\text {_value }}>\alpha$ sehingga $\mathrm{H} 0$ di terima, berarti tidak ada hubungan akses informasi dengan pemilihan tempat persalinan oleh Ibu di Kelurahan Muara Rapak

Tabel 5 Hubungan Faktor Peserta JKN dengan Pemilihan Tempat Persalinan

\begin{tabular}{|c|c|c|c|c|c|c|c|c|c|c|}
\hline \multirow[t]{3}{*}{ Peserta JKN } & \multicolumn{8}{|c|}{ Tempat Persalinan } & \multirow[t]{3}{*}{ Total } & \multirow[t]{3}{*}{ P_value } \\
\hline & \multicolumn{2}{|c|}{ RS } & \multicolumn{2}{|c|}{ BPM } & \multicolumn{2}{|c|}{ Klinik } & \multicolumn{2}{|c|}{ Dukun } & & \\
\hline & $\mathbf{n}$ & $\%$ & $\mathbf{n}$ & $\%$ & n & $\%$ & $\mathbf{n}$ & $\%$ & & \\
\hline JKN & 72 & 82.8 & 4 & 4.6 & 9 & 10.3 & 2 & 2.3 & 87 & 0.001 \\
\hline Tidak JKN & 1 & 20 & 2 & 40 & 1 & 20 & 1 & 20 & 5 & \\
\hline Total & 73 & 79.3 & 6 & 6.5 & 10 & 10.9 & 3 & 3.3 & 92 & \\
\hline
\end{tabular}

Berdasarkan tabel 5 menunjukkan hubungan faktor peserta JKN dengan pemilihan tempat persalinan yaitu kategori peserta menggunakan JKN sebanyak 87 responden dari 92 orang, terbanyak memilih tempat persalinan rumah sakit sebanyak $72 \quad(82.8 \%)$ responden, yang kedua memilih tempat persalinan yaitu di klinik bersalin sebanyak $9(10.3 \%)$ responden, memilih bersalin di BPM sebanyak 4 dukun / di rumah sebanyak 2 (2.3\%) responden. Sedangkan hubungan faktor yang tidak memiliki peserta JKN dengan pemilihan tempat persalinan yaitu 5 responden dari 92 orang, terbanyak memilih tempat persalinan di di BPM sebanyak 2 (40\%) responden, selanjutnya yang memilih tempat persalinan di RS sebanyak 1 (20\%) responden, memilih bersalin di klinik 
bersalin sebanyak 1 (20\%), dan memilih tempat bersalin di dukun beranak / di rumah sebanyak $1(20 \%)$ responden.

Hasil uji statistik Chi-Square diperoleh nilai $\mathrm{p}=0.001$ dengan demikian p_value $<\alpha$ sehingga H0 di tolak, berarti tidak ada hubungan kepesertaan JKN dengan pemilihan tempat persalinan oleh ibu di Kelurahan Muara Rapak.

\section{Pembahasan}

1. Variabel Pemilihan Tempat persalinan

Bedasarkan pengolahan data, dari total 92 responden, paling banyak (79.3\%) responden memilih tempat persalinan di rumah sakit, kemudian $10.9 \%$ responden memilih tempat persalinan di klink bersalin, $6.5 \%$ memilih tempat bersalin di BPM, dan $3.3 \%$ responden memilih tempat persalinan di dukun beranak / di rumah.

Hasil penelitian Gillian Houghton tentang faktor-faktor yang mempengaruhi pemilihan tempat persalinan, menyimpulkan bahwa banyak responden percaya bahwa persalinan di rumah sakit lebih aman daripada melakukan persalinan di rumah atau tempat bersalin lainnya. Selain itu, para ibu dan tenaga kesehatan merasa lebih nyaman ketika persalinan dilakukan di rumah sakit.(Gillian Houghton, Carol Bedwell, Mary Forsey \& Lavender, 2008)

Hasil penelitian ini menunjukkan rumah sakit adalah tempat persalinan yang paling banyak dipilih oleh responden. Hal ini dimungkinkan dengan adanya rumah sakit di Kota Balikpapan yang terdiri dari beberapa rumah sakit dengan fasilitas lengkap untuk pelayanan persalinan, sehingga membuat lebih banyak responden memilih tempat persalinan di rumah sakit daripada tempat persalinan lainnya.

Resiko yang tinggi pada kehamilan harus diikuti dengan kebijakan untuk memilih tenaga penolong persalinan karena jika ibu memiliki resiko dalam mengahadapi persalinan, hendaknya lebih bijak dalam menentukan penolong tenaga persalinan. Namun karakteristik masyarakat ditinjau dari beberapa aspek seperti usia dan pendidikan, bukan merupakan faktor yang secara langsung berkaitan dengan pemilihan terhadap tempat persalinan. Keputusan dalam pemilihan tempat persalinan lebih dimungkinkan dengan persepsi tentang rasa aman dan kenyamanan dari suatu fasilitas tempat persalinan. 
Berdasarkan Green dan Kreuter(Kreuter., 2001) terdapat beberapa faktor yang berpengaruh terhadap perilaku kesehatan, dalam hal ini perilaku ibu melahirkan dalam mendapatkan pelayanan kesehatan. Perilaku ingin memilih tempat persalinan tertentu dapat terbentuk dari faktor pemungkin (enabling factors), diantaranya adalah kelengkapan fasilitas suatu sarana kesehatan.

2. Variabel Pendapatan Keluarga

Hasil uji statistik menunjukkan bahwa tidak ada hubungan pendapatan dengan pemilihan tempat persalinan oleh ibu di Kelurahan Muara Rapak. Hasil penelitian ini tidak sama dengan hasil penelitian Gita Sekar tentang analisis faktor pemilihan tempat bersalin di rumah sakit pada ibu hamil, yang menyimpulkan bahwaterdapat hubungan antara karakteristik tingkat ekonomi terhadap pemilihan tempat bersalin.(Gita Sekar Prihanti1, Ekky Dwi Rahmawan, Lusiana Kusuma Wardhani, Juanda Akbar, Dysca Ryesnanda Ayunita, Farahiya Nabila, Galuh Supriyadi, 2016)

Hakekatnya, pendapatan keluarga mempengaruhi keluarga dalam membayar pelayanan kesehatan yang dibutuhkan, seperti pertolongan persalinan, membeli obat, membayar biaya pelayanan, membayar biaya transportasi ke tempat pelayanan kesehatan dan sebagainya. Semakin besar pendapatan dalam keluarga, maka semakin besar peluang ibu dan keluarga untuk memilih fasilitas kesehatan sebagai tempat persalinan. Karakteristik masyarakat ditinjau dari pendapatan keluarga merupakan faktor yang secara tidak langsung turut mempengaruhi kondisi sosial ekonomi keluarga sehingga juga akan mempengaruhi keluarga dalam pemanfaatan sarana kesehatan sebagai tempat persalinan.

Namun dalam hal ini, bersadarkan kesimpulan hasil penelitian ini, sebuah keluarga dengan pendapatan tinggi atau rendah dapat tetap memilih jenis tempat persalinan yang sama. Hal ini lebih dimungkinkan karena suatu keluarga lebih mengandalkan pelayanan kesehatan sebagai peserta JKN sehingga masalah pendapatan keluarga bukan hal yang menjadi pertimbangan dalam menentukan tempat persalinan ibu.

\section{Variabel Biaya Persalinan}

Hasil uji statistik menunjukkan bahwa tidak ada hubungan biaya bersalin dengan pemilihan tempat persalinan oleh ibu di Kelurahan Muara Rapak. Hasil penelitian ini tidak sama 
dengan hasil penelitian Rusnawati tentang faktor-faktor yang berhubungan dengan pemilihan tempat persalinan di wilayah kerja Puskesmas Negara Kecamatan Daha Utara Kabupaten Hulu Sungai Selatan Propinsi Kalimantan Selatan, yang menyimpulkan bahwa ada hubungan yang bermakna antara biaya persalinan dengan pemilihan tempat persalinan.(Rusnawati, 2012)

Ditinjau dari biaya persalinan, meskipun RS, klinik bersalin maupun PBM menerapkan tarif biaya tertentu, namun dalam hal ini, berapapun biaya persalinan yang ditetapkan oleh sarana kesehatan tersebut, responden dapat tetap memilih tempat persalinan yang dikehendaki. Pilihan ini lebih dimungkinkan karena suatu keluarga lebih mengandalkan pelayanan kesehatan sebagai peserta JKN sehingga masalah biaya persalinan bukan hal yang menjadi pertimbangan dalam menentukan tempat persalinan ibu.

\section{Variabel Akses Informasi}

Hasil uji statistik menunjukkan bahwa tidak ada hubungan antara akses informasi dengan pemilihan tempat persalinan oleh Ibu di Kelurahan Muara Rapak. Hasil penelitian ini berbeda dengan hasil penelitian dengan penelitian Dwi Putri yang menyimpulkan bahwa ada hubungan yang bermakna antara pengetahuan responden dengan pemilihan tempat persalinan.(Putri, 2016)

Menurut Notoatmodjo, semakin tinggi pendidikan seseorang maka semakin banyak bahan, materi atau pengetahuan seseorang. Artinya, semakin tinggi tingkat pendidikan seseorang, maka akan berpengaruh terhadap akses informasi dan pemahaman tentang suatu permasalahan yang akan memengaruhi perilakunya khususnya perilaku kesehatan.(Notoadmojo, 2007) Pemahaman akan persalinan, bahaya/komplikasi persalinan, kemudahan mendapatkan penanganan medis akan memotivasi dan mengarahkan ibu untuk bersalin di fasilitas kesehatan dengan tenaga kesehatan yang kompeten.

Menurut teori Green dan Kreuter, bahwa perilaku manusia terbentuk dari faktor predisposing (predisposing factors), faktor pemungkin (enabling factors) dan faktor penguat (reinforcing factors).(Kreuter., 2001) Pengetahuan merupakan salah satu dari faktor predisposing sehingga pengetahuan berperan dalam pembentukan perilaku manusia. Sehingga dalam pemilihan 
tempat persalinan, pengetahuan tentang persalinan dan tempat persalinan merupakan domain yang sangat penting untuk terbentuknya perilaku seorang ibu dalam hal pemilihan tempat persalinan.(Kreuter., 2001)

Peningkatan pengetahuan pada ibu bersalin dapat dilakukan melalui berbagai cara diantaranya peningkatan akses informasi melalui kelas ibu hamil, Posyandu, media massa dan petugas kesehatan dimana sangat penting untuk lebih mendekatkan akses informasi pada ibu tentang pentingnya persalinan difasilitas kesehatan. Semakin baik pengetahuan ibu terhadap kehamilan dan persalinan maka semakin besar kemungkinan ibu memanfaatkan pelayanan kesehatan.

Namun pemilihan tempat persalinan yang tidak berhubungan dengan akses informasi pada ibu, hal ini dapat terjadi karena di Kota Balikpapan terdapat banyak fasilitas kesehatan yang melayani persalinan, dengan jarak yang saling berdekatan. Tempat persalinan akan sangat mudah dapat diketahui dan dapat dijangkau dalam waktu relatif singkat, dengan alat transportasi yang mudah didapatkan. Selain itu, dengan kemajuan teknologi, informasi tempattempat persalinan langsung dapat diakses melalui telepon genggam dengan jaringan internet.

5. Variabel Peserta Jaminan

Kesehatan Nasional

Hasil uji statistik menunjukkan bahwa tidak ada hubungan kepesertaan JKN dengan pemilihan tempat persalinan oleh ibu di Kelurahan Muara Rapak. Hasil penelitian ini sejalan dengan hasil penelitian Debra tentang faktor-faktor yang berhubungan dengan pemanfaatan pelayanan kesehatan pada peserta BPJS kesehatan di Puskesmas Paniki Bawah Kecamatan Mapanget Kota Manado menunjukkan ada hubungan yang bermakna antara persepsi responden tentang JKN.(Kandou, Debra S. S. Rumengan, J. M. L. Umboh, 2015)

Sesuai dengan Peraturan Menteri Kesehatan (PMK) Republik Indonesia nomor 71 tahun 2013 tentang Pelayanan kesehatan pada Jaminan Kesehatan nasional, bagi peserta JKN dapat memperoleh pelayanan kesehatan sesuai ketersediaan pelayanan pada suatu unit pelayanan kesehatan, yaitu pada pelayanan kesehatan tingkat pertama dan pelayanan kesehatan rujukan tingkat lanjutan.(Kementerian Kesehatan RI, 2013) 
Oleh karena itu, maka keputusan memilih tempat persalinan oleh responden disimpulkan terkait dengan kepesertaan JKN, yang mana sebagai peserta JKN ada kejelasan jaminan ibu bersalin dalam hal pembiayaan persalinan. Anggapan masyarakat bahwa biaya persalinan mahal, tidak lagi menjadi masalah bagi anggota masyarakat yang menjadi peserta JKN. Selain itu, karena sebagai peserta JKN tidak ada pembatasan jumlah kelahiran yang dijamin oleh BPJS.

\section{SIMPULAN}

Tidak ada hubungan antara pendapatan keluarga, biaya persalinan, akses informasi dengan pemilihan tempat persalinan. Namun ada hubungan antara kepesertaan Jaminan Kesehatan Nasional pemilihan tempat persalinan oleh ibu di Kelurahan Muara Rapak Balikpapan. Melalui hasil penelitian ini diharapkan tempat penelitian dapat meningkatkan kemitraan dengan tempat persalinan dan memfasilitasi ibu yang akan memilih tempat persalinan di sarana pelayaan kesehatan

\section{DAFTAR PUSTAKA}

Balikpapan, D. K. K. (2016). Profil
Kesehatan. Balikpapan.

Gillian Houghton, Carol Bedwell, Mary Forsey, L. B., \& Lavender, T. (2008). Factors influencing choice in birth place - an exploration of the views of women, their partners and professionals. The Royal Collage of Midwives, (Evidence Based Midwifery).

Gita Sekar Prihanti1, Ekky Dwi Rahmawan, Lusiana Kusuma Wardhani, Juanda Akbar, Dysca Ryesnanda Ayunita, Farahiya Nabila, Galuh Supriyadi, I. B. K. W. (2016). Analisis Faktor Pemilihan Tempat Bersalin di Rumah Sakit pada Ibu Hamil. Helen Varney, H.Kriebs, J. M. G. (2007). Buku Ajar Asuhan Kebidanan. Jakarta: EGC.

Hoelman, M. B., Parhusip, B. T. P., Eko, S., Bahagijo, S., \& Santono, H. (2015). Panduan SDGs (Sustainable Development Goals) untuk Pemerintah Daerah.

Indonesia, K. K. R. (2012). Survei Kesehatan Dasar Indonesia.

International, B. K. dan K. B. N. B. P. S. K. K. M. D. I. (2013). Survei Demografi dan Kesehatan Indonesia. Jakarta: Badan Penelitian dan Pengembangan 
Kesehatan

Kementerian

Kesehatan.

Kandou, Debra S. S. Rumengan, J. M.

L. Umboh, G. D. (2015). Faktor-

Faktor yang Berhubungan dengan

Pemanfaatan Pelayanan Kesehatan

Pada Peserta BPJS Kesehatan di

Puskesmas Paniki Bawah

Kecamatan Mapanget Kota

Manado. JIKMU, 5 No. 1.

Kementerian Kesehatan RI. Peraturan

Menteri Kesehatan Republik

IndonesiaNomor 71 Tahun 2013

Tentang Pelayanan Kesehatan

Pada Jaminan Kesehatan Nasional (2013).

Kesehatan, K. (2010). Rencana

Strategis Kementerian Kesehatan

Tahun 2010-2014. Jakarta:

Kementerian Kesehatan.

Kreuter., G. L. W. and M. W. (2001).

Health Promotion Planning: An

Educational and Ecological

Approach (3rd ed.). Mayfield

Publishing.

Manuaba. (2006). Ilmu Kebidanan;

Penyakit Kandungan dan Keluarga

Berencanauntuk Pendidikan

Bidan. Jakarta: EGC.

Notoadmojo, S. (2007). Promosi

Kesehatan dan Ilmu Perilaku.

Jakarta: Rineka Cipta.
Notoatmodjo, S. (2012). Metodologi Penelitian Kesehatan. Jakarta: Rineka Cipta.

Prawirohardjo, S. (2005). Ilmu Kebidanan. Jakarta: Yayasan Bina Pustaka Sarwono Prawirohardjo.

Prawiroharjo, S. (2011). Ilmu Kebidanan. Jakarta: Bina Pustaka Sarwono Prawirohardjo.

Putri, M. D. (2016). Faktor-faktor yang Berhubungan Dengan Pemilihan Tempat Persalinan Tahun 2015 (Studi Di Kecamatan Sarolangun Kabupaten Sarolangun Jambi). Jurnal Kesehatan Masyarakat (EJournal), 4.

Rusnawati. (2012). Faktor-faktor yang berhubungan dengan pemilihan tempat persalinan di wilayah kerja Puskesmas Negara Kecamatan Daha Utara Kabupaten Hulu Sungai Selatan Propinsi Kalimantan selatan. 